\title{
Enantioselective hydrolysis of racemic naproxen nitrile and naproxen amide to $S$-naproxen by new bacterial isolates
}

\author{
Norman Layh ${ }^{\text {a }}$, Andreas Stolz ${ }^{\text {a }}$, Joachim Böhme b , Franz Effenberger ${ }^{\text {b }}$, \\ Hans-Joachim Knackmuss a,* \\ ${ }^{a}$ Institut für Mikrobiologie der Universität Stuttgart, Allmandring 31, 70569 Stuttgart, Germany, \\ ${ }^{b}$ Institut für Organische Chemie der Universität Stuttgart, Germany
}

(Accepted 2 September 1993)

\begin{abstract}
Bacteria were enriched from soil samples with succinate as a carbon source and racemic naproxen nitrile [2-(6-methoxy-2-naphthyl)propionitrile] as sole source of nitrogen. Since naproxen nitrile was only poorly soluble in water media amended with different water-immiscible organic phases were used for the enrichments. With pristane (2,6,10,14-tetramethylpentadecane) as the organic phase two bacterial strains were isolated (strain C3II and strain MP50) which were identified as rhodococci. Cells of both strains converted naproxen nitrile via naproxen amide to naproxen. From racemic naproxen nitrile Rhodococcus sp. C3II formed $S$-naproxen amide and subsequently $S$-naproxen. Racemic naproxen amide was hydrolysed to $S$-naproxen. Rhodococcus sp. MP50 converted racemic naproxen nitrile predominantly to $R$-naproxen amide and racemic naproxen amide to $S$-naproxen. With both strains racemic naproxen amide was converted to $S$-naproxen with an enantiomeric excess $>99 \%$ at a conversion rate up to $80 \%$ of the theoretical value. In strain C3II the enzymes which hydrolysed naproxen nitrile and naproxen amide were present only at a low constitutive level. In contrast, in Rhodococcus sp. MP50 these activities were induced when grown in the presence of various nitriles.
\end{abstract}

Key words: Amidase; Enantioselective enzyme; Naproxen; Nitrile; Nitrile hydratase; Rhodococcus

\section{Introduction}

2-Arylpropionic acids such as ibuprofen and naproxen are important non-steroidal antiinflammatory drugs (Shen, 1972). They contain a chiral center and in vitro studies on inhibition of prostaglandin synthesis show that their activity resides almost exclusively in the $S(+)$-isomers

\footnotetext{
* Corresponding author.
}

(Caldwell et al., 1988). In the case of naproxen the $S$-form is 28 -fold more active than the corresponding $R$-enantiomer (Harrison et al., 1970; Roszkowski et al., 1971).

Up to now the chiral synthesis of $S$-naproxen was achieved by chemical methods (Tsuchihashi et al., 1982; Franck and Rüchardt, 1984; Giordano et al., 1984; Castaldi et al., 1987; Parrinello and Stille, 1987; Wolber and Rüchardt, 1991; Sonawane et al., 1992; Brown, 1992) and by enantioselective hydrolysis of racemic esters of 
naproxen using microbial esterases ( $\mathrm{Gu}$ et al., 1986; Battistel et al., 1991). In the present study the ability of two bacterial strains to produce pure $S$-naproxen (e.e. $>99 \%$ ) from racemic naproxen nitrile or naproxen amide is described.

\section{Materials and methods}

\section{Chemicals}

Racemic naproxen nitrile (NapN) and naproxen amide (NapA) were prepared from 2methoxynaphthalene and racemic ibuprofen nitrile from isobutylbenzene (Arsenijevic et al., 1973; Hall and Gisler, 1976; Hiyama et al., 1986). $S$-Naproxen was obtained from Sigma (Deisenhofen). $S$-NapA was synthesized from $S$-Nap via the corresponding acid chloride. Octane, nonane, pristane, heptamethylnonane and diethyl phosphoramidate were supplied from Aldrich (Steinheim, Germany). Naphthalene-2-carbonitrile and 2-naphthalenecarboxamide were purchased from Lancaster Synthesis (Eastgate, UK) and naphthalene-2-carboxylic acid from Fluka (Buchs, Switzerland). All other culture media, chemicals and apparatus were the same as described before (Layh et al., 1992).

\section{Media}

Bacterial cultures were grown in a nitrogenfree mineral medium according to Layh et al. (1992) with succinate (10 mM) as sole source of carbon and energy. Naproxen nitrile was added as sole source of nitrogen. Naproxen nitrile was dissolved in methanol (stock solution: 20 or 40 $\mathrm{mM})$ or in a water-immiscible organic phase and added to the cultures to a final concentration of $0.5 \mathrm{mM}$. In certain experiments mineral media containing ammonia were used as described by Dorn et al. (1974).

\section{Isolation of microorganisms}

Bacterial cultures were isolated by enrichment from soil in Erlenmeyer flasks with baffles (300 $\mathrm{ml}$ with $15 \mathrm{ml}$ of medium) on a rotary shaker (100 rpm). Enrichments were started with different soils taken from the area of Stuttgart (Germany) and carried out in a nitrogen free mineral salts medium containing succinate $(10 \mathrm{mM})$ as carbon source, naproxen nitrile $(0.5 \mathrm{mM})$ as a nitrogen source and different organic solvents (see Results). After 1 week incubation cultures were transferred $(1: 10 \mathrm{v} / \mathrm{v})$ to fresh medium with the same composition. These cultures were transferred (after 1 week) to agar plates (mineral medium with succinate and $\mathrm{NapN}$ ) and single colonies purified by standard methods on solid media. After two transfers single colonies were used to inoculate aqueous organic media as described above. After $9 \mathrm{~d}$ incubation the aqueous phases were analyzed by HPLC for the formation of naproxen (Nap). The Nap forming cultures were purified on Nutrient Broth-agar plates, transferred to succinate/NapN-agar and finally grown in liquid culture with NapN as sole nitrogen source.

Initial characterization and taxonomic classification of the isolates

Strain C3II and MP50 formed on Nutrient Broth agar plates white mucoid colonies, which reached a diameter of about $5 \mathrm{~mm}$ after $3 \mathrm{~d}$ incubation at $30^{\circ} \mathrm{C}$. Strain C3II and MP50 were Gram-positive non motile rods. Strain C3II formed in aqueous cultures structures resembling the 'snapping' of coryneform bacteria (Stanier et al., 1976). The isolates were characterized by using the API Coryne test (API-System S.A., La Balme les Grottes, France). Thus strain C3II and MP50 were found to belong to Rhodococcus equi (probability for strain $\mathrm{C} 3 \mathrm{II}=93 \%$ and for strain MP50 $=99.8 \%$ ). According to Dr. R. Kroppenstedt (Deutsche Sammlung von Mikroorganismen (DSM); Braunschweig, Germany) strain C3II belongs most probably to a yet undescribed species in the genus Rhodococcus.

\section{Analytical methods}

The formation of naproxen was analyzed by HPLC. If no separation of enantiomers was necessary a reverse-phase column (Grom-Sil C8; Grom, Herrenberg, Germany) was used (solvent system: $45 \%(\mathrm{v} / \mathrm{v})$ acetonitrile, $54.7 \%(\mathrm{v} / \mathrm{v})$ water, $0.3 \%(\mathrm{v} / \mathrm{v}) \mathrm{H}_{3} \mathrm{PO}_{4}$ ). For separation of the enantiomers of naproxen (Nap) an AGP-column (with guard column) (column size: $100 \times 4 \mathrm{~mm}$; 5 
$\mu \mathrm{m}$ silicagel particles with $\alpha_{1}$-acid glycoprotein; ChromTech, Norsborg, Sweden) with $10 \mathrm{mM}$ Na-phosphate buffer pH 7.0 as solvent was used (flow rate $0.9 \mathrm{ml} \mathrm{min}^{-1} ; R_{\mathrm{t}}(S-\mathrm{Nap})=5.7 \mathrm{~min}, R_{\mathrm{t}}$ $(R$-Nap $)=3.5 \mathrm{~min})$. For the separation of the enantiomers of naproxen amide (NapA) a HSAcolumn (with guard column) (column size: $100 \times 4$ $\mathrm{mm} ; 5 \mu \mathrm{m}$ silicagel particles with human serum albumin; ChromTech), with $100 \mathrm{mM}$ Na-phosphate buffer, $\mathrm{pH} 7.0$ and $5 \%(\mathrm{v} / \mathrm{v})$ isopropanol as

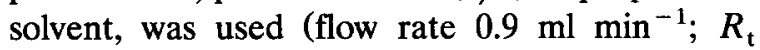
$(S$-NapA $)=17 \mathrm{~min}, R_{\mathrm{t}}(R$-NapA $\left.)=15 \mathrm{~min}\right)$. The enantiomeric excess (e.e.) was defined as the ratio $((R-S) /(R+S)) \times 100 \%$ (or vice versa), where $R$ and $S$ are, respectively, the concentrations of the $R$ - and $S$-enantiomers. The e.e. values were calculated by comparison of the peak areas obtained by HPLC analysis.

The identity of $S$-Nap was determined by cochromatography with an enantiopure standard (Sigma, Deisenhofen). All other chromatographic conditions have been described before (Layh et al., 1992).

For the determination of enzyme activities resting cells $\left(A_{546 \mathrm{~nm}}=0.05-20\right.$ in $50 \mathrm{mM} \mathrm{Na} / \mathrm{K}$ phosphate buffer, $\mathrm{pH} 7.4$ ) were incubated on a rotary shaker at $30^{\circ} \mathrm{C}$ with naproxen nitrile or naproxen amide. Every $3 \mathrm{~min}$ aliquots $(0.15 \mathrm{ml})$ were taken, cells removed by centrifugation ( 3 min, $14000 \mathrm{rpm}$ ) and the supernatants analysed by HPLC for the formation of naproxen.

\section{Growth measurement}

Growth of bacterial cultures was monitored spectrophotometrically by measuring the optical density at $546 \mathrm{~nm}$ with a Kontron Uvikon 820 Spectrophotometer (Kontron, Eching, Germany). For both strains an optical density $\left(A_{546 \mathrm{~nm}}\right)$ of 1 corresponded to $220 \mathrm{mg}$ of bacterial dry weight per liter of culture.

\section{Results}

\subsection{Isolation of bacteria}

Bacteria were enriched from soil in a nitrogenfree mineral medium containing succinate (10

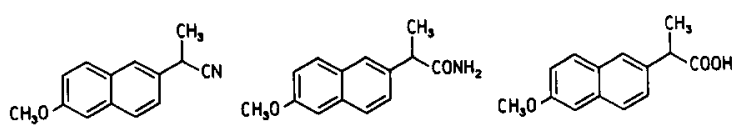

Fig. 1. Structural formulas of naproxen nitrile (left), naproxen amide (middle) and naproxen (right).

$\mathrm{mM})$ as carbon source and naproxen nitrile $(0.5$ $\mathrm{mM}$; Fig. 1) as sole source of nitrogen. Naproxen nitrile (NapN) was only slightly soluble in aqueous media. Therefore NapN was dissolved in methanol or different water-immiscible organic solvents and the solutions added to the different enrichment cultures. Octane, nonane, pristane or heptamethylnonane $(10-50 \%(\mathrm{v} / \mathrm{v}))$ were used as the substrate carrying organic phases. The strains C3II and MP50 were obtained from different enrichment cultures with pristane as the organic phase. NapN-dependent growth of strain C3II and MP50 on agar plates with succinate $(10 \mathrm{mM})$ and NapN (1 mM) suspended as fine particles resulted in the disintegration of crystalline NapN forming a clear halo around the colonies.

The two isolates were designated tentatively as Rhodococcus sp. C3II and Rhodococcus sp. MP50 (see Material and methods).

\subsection{Formation of naproxen from naproxen nitrile by resting cells of Rhodococcus sp. C3II and Rhodococcus sp. MP50}

The isolates were grown with succinate (10 $\mathrm{mM})$ and NapN (0.5 mM) as nitrogen source. Cells were harvested by centrifugation and resting cells $\left(A_{546 \mathrm{~nm}}=4-5\right)$ were incubated with NapN (0.3 mM, dissolved in methanol). By HPLC the formation of naproxen (Nap) $\left(R_{\mathrm{t}}=4.1 \mathrm{~min}\right)$ and naproxen amide (NapA) $\left(R_{\mathrm{t}}=2.9 \mathrm{~min}\right)$ from NapN $\left(R_{\mathrm{t}}=7.8 \mathrm{~min}\right)$ was demonstrated. Due to the low solubility of NapN in water during almost the entire experiment the apparent concentration of NapN in the aqueous phase was constant and low (about $0.04 \mathrm{mM}$ ). Only at the end of the biotransformation it dropped to zero.

With both strains NapA accumulated during the first minutes and its concentration slowly decreased towards the end of the experiment. The maximal concentrations of NapA were 30 
$50 \%$ of the starting concentration of NapN. Nap was not further metabolized indicating that the isolates could not use it as a carbon source.

\subsection{Formation of S-naproxen from racemic na-} proxen nitrile or naproxen amide by Rhodococcus sp. C3II

Resting cells of strain C3II $\left(A_{546 \mathrm{~nm}}=4.4\right)$ were incubated in two separate flasks with NapN or NapA ( $0.2 \mathrm{mM}$ each). Within the initial $5 \mathrm{~min}$ turn-over of racemic NapN resulted in the predominant formation of $S$-NapA (enantiomeric excess (e.e.) $=43 \%$ ). Subsequently the concentration of $S$-NapA decreased. Thereby, the e.e. of $R$-NapA increased to an e.e. value $>99 \%$. After $15 \mathrm{~min} 40 \%$ of the racemic NapN was transformed to $S$-Nap with an e.e. $>99 \%$. Later on small amounts of $R$-Nap appeared in the supernatant. The specific activity for the formation of $S$-Nap from NapN was only $0.0034 \mu \mathrm{mol} \mathrm{min}^{-1}$ and mg of dry weight. For the formation of NapA

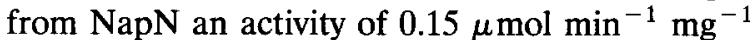
was observed. In a parallel experiment with racemic NapA as a substrate it was found that about one half of the substrate was rapidly converted to $S$-Nap. After conversion of $39 \%$ an e.e. of $98.5 \%$ was found (Fig. 2). In both experiments the formation of $S$-Nap proceeded with almost the same velocity. It was thus concluded that the nitrile hydratase activity was significantly higher than the amidase activity and that hydrolysis of NapA to $S$-Nap was the enantioselective and rate-limiting step.

\subsection{Formation of $S$-naproxen from racemic na-} proxen nitrile or naproxen amide by Rhodococcus sp. MP50

The Nap formed from NapN (0.3 mM) by resting cells of Rhodococcus sp. MP50 ( $A_{546 \mathrm{~nm}}=$ 4.6) showed only a low enantiomeric excess for $S$-Nap (e.e. $\leq 47 \%$ ). In contrast, enantiomeric pure $R$-NapA was found (e.e. $>99 \%$ ). In a parallel experiment racemic NapA $(0.3 \mathrm{mM})$ was incubated with resting cells of Rhodococcus sp. MP50 $\left(A_{546 \mathrm{~nm}}=0.05\right)$. This resulted in the formation of pure $S$-Nap (e.e. $>99 \%$ ) until $46 \%$ of the racemic

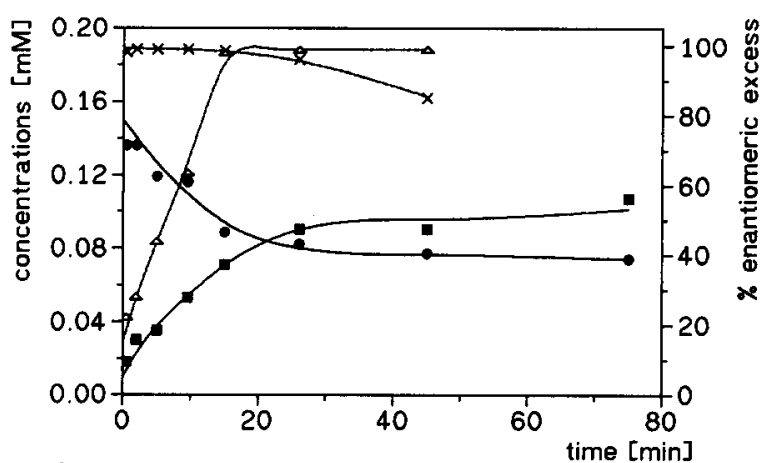

Fig. 2. Conversion of naproxen amide to naproxen by resting cells of Rhodococcus sp. C3II. Strain C3II was grown in a mineral medium $\left(\mathrm{NH}_{4}\right.$-containing) with succinate $(10 \mathrm{mM})$ and Nutrient Broth $\left(0.45 \mathrm{~g}^{-1}\right)$. Cells were harvested by centrifugation and resuspended in $\mathrm{Na} / \mathrm{K}$-phosphate buffer (pH 7.4, $50 \mathrm{mM}$ ) to an optical density $A_{546 \mathrm{~nm}}=4.4$. Naproxen amide was added to a starting concentration of $0.2 \mathrm{mM}$ (stock solution: $20 \mathrm{mM}$ in methanol). At the indicated time intervals aliquots $(0.15 \mathrm{ml})$ were taken and bacterial cells removed by centrifugation ( $3 \mathrm{~min}, 14000 \mathrm{rpm})$. The supernatants were analyzed using a reverse-phase column (naproxen ( $\boldsymbol{\omega})$; naproxen amide ( $\bullet)$ ). The e.e. values of $S$-naproxen $(X)$ and $R$-naproxen amide $(\Delta)$ were calculated by comparison of the peak areas of the respective $S$ - and $R$-enantiomers obtained by chiral HPLC-analysis.

NapA was converted. The remaining NapA was pure $R$-NapA (Fig. 3). The specific activity for the formation of $S$-Nap from racemic NapA was $0.74 \mu \mathrm{mol} \mathrm{min}{ }^{-1} \mathrm{mg}^{-1}$.

\subsection{Enantioselectivity of the nitrile hydratases from Rhodococcus sp. C3II and Rhodococcus sp. MP50}

A dilute suspension of resting cells of Rhodococcus sp. C3II $\left(A_{546 \mathrm{~nm}}=0.73\right)$ was incubated with NapN. Turnover of the amide was the rate-limiting step during biotransformation of NapN (see above). Therefore at a low cell concentration the nitrile was mainly converted to the amide and only low amounts of Nap were formed ( $<2 \%$ compared to the amide). Thus it was found that preferentially $S$-NapA was formed from racemic NapN. The highest e.e. of $S$-NapA was $94 \%$ after $30 \%$ turnover.

During the turnover of NapN by Rhodococcus sp. MP50 the formation of enantiopure $R$-NapA had been observed (see above). This could be 


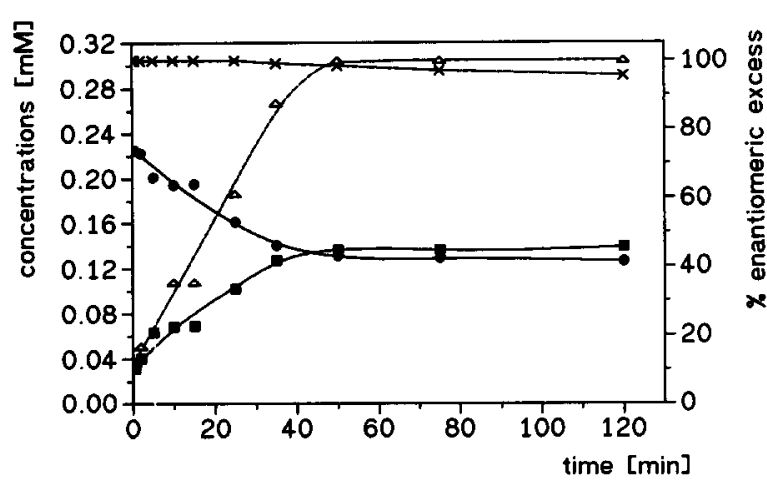

Fig. 3. Formation of $S$-naproxen from racemic naproxen amide by resting cells of Rhodococcus sp. MP50. Strain MP50 was grown in a mineral medium with succinate $(10 \mathrm{mM})$ and naproxen amide $(0.5 \mathrm{mM})$. Cells were harvested by centrifugation and resuspended in $\mathrm{Na} / \mathrm{K}$-phosphate buffer $(\mathrm{pH} \mathrm{7.4,50}$ $\mathrm{mM}$ ) to an optical density $A_{546 \mathrm{~nm}}=0.05$. Naproxen amide was added to a starting concentration of $0.3 \mathrm{mM}$ (stock solution: $20 \mathrm{mM}$ in methanol). At the indicated time intervals aliquots $(0.15 \mathrm{ml})$ were taken and bacterial cells removed by centrifugation ( $3 \mathrm{~min}, 14000 \mathrm{rpm}$ ). The supernatants were analyzed using a reverse-phase column (naproxen ( $\square$ ); naproxen amide $(\bullet))$. The e.e. values of $S$-naproxen $(X)$ and $R$-naproxen amide $(\Delta)$ were calculated by comparison of the peak areas of the respective $S$ - and $R$-enantiomers obtained by chiral HPLC-analysis.

either explained by a highly enantioselective nitrile hydratase forming $R$-NapA or by the highly active enantioselective amidase which converted all $S$-NapA formed by the nitrile hydratase. To answer this question resting cells were incubated with NapN and diethyl phosphoramidate to inhibit the amidase (Dr. Piel, personal communication). Actually the nitrile hydratase from Rhodococcus sp. MP50 formed $R$-NapA from NapN with a low enantiomeric excess (Fig. 4).

\subsection{Induction of the naproxen nitrile and naproxen amide hydrolysing activities in Rhodococcus sp. C3II and Rhodococcus sp. MP50}

In Rhodococcus sp. C3II the activity that converted NapN to Nap was constitutively expressed and also found in cells grown with ammonia as nitrogen source.
Strain MP50 was grown with succinate (10 $\mathrm{mM})$ and NapN or NapA (0.5 mM each) in mineral media with or without added ammonia. The cells were harvested and resting cells incubated with NapN or NapA ( $0.5 \mathrm{mM}$ each). After growth with NapN without ammonia the turnover rate of NapN was $0.003 \mu \mathrm{mol} \mathrm{min}{ }^{-1} \mathrm{mg}^{-1}$ of dry weight and of NapA was $0.71 \mu \mathrm{mol} \mathrm{min}{ }^{-1} \mathrm{mg}^{-1}$. Surprisingly, after growth with NapN or NapA in the presence of ammonia only $2-4 \%$ of the respective enzyme activities were found. After growth with NapA without added ammonia only the amide hydrolysing activity $\left(0.73 \mu \mathrm{mol} \mathrm{min}^{-1} \mathrm{mg}^{-1}\right.$ of dry weight), but no nitrile converting enzyme was induced. Induction of these activities $(=90$ $120 \%$ of the value found with NapN) was also observed after growth with benzylcyanide, $\alpha$ methylbenzylcyanide, isobutyronitrile, isovaleronitrile or urea.

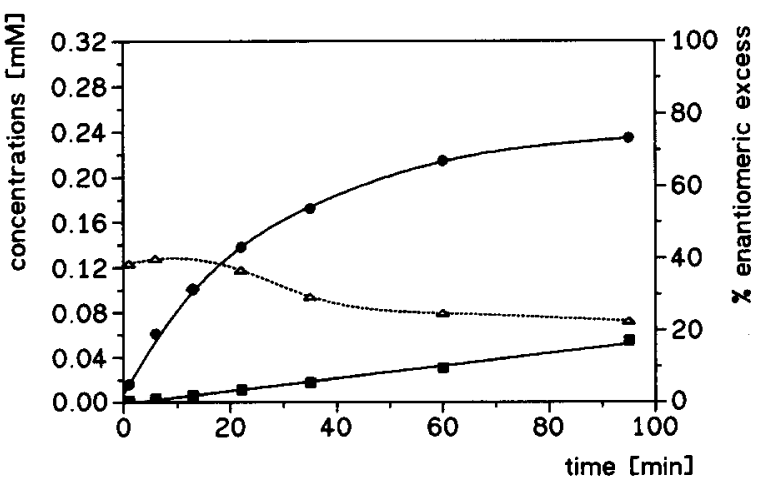

Fig. 4. Conversion of naproxen nitrile to naproxen amide by resting cells of Rhodococcus sp. MP50 in the presence of diethyl phosphoramidate. Strain MP50 was grown overnight in a mineral medium with succinate $(10 \mathrm{mM})$ and naproxen nitrile $(0.5 \mathrm{mM})$. Cells were harvested by centrifugation and

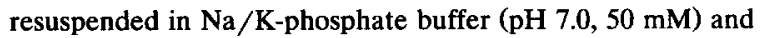
diethyl phosphoramidate $(20 \mathrm{mM})$ to an optical density $A_{546 \mathrm{~nm}}=36$. Naproxen nitrile was added to a starting concentration of $0.3 \mathrm{mM}$ (stock solution: $20 \mathrm{mM}$ in methanol). At the indicated time intervals aliquots $(0.15 \mathrm{ml})$ were taken and bacterial cells removed by centrifugation ( $3 \mathrm{~min}, 14000 \mathrm{rpm}$ ). The supernatants were analyzed using a reverse-phase column (naproxen ( $\square$ ); naproxen amide ( $\bullet$ ). The e.e. of $R$-naproxen amide $(\Delta)$ was calculated by comparison of the peak areas of the $S$ - and $R$-enantiomers obtained by chiral HPLC-analysis. 
Table 1

Conversion of different nitriles and amides by resting cells of Rhodococcus sp. C3II and MP50

\begin{tabular}{lcc}
\hline Compound & \multicolumn{2}{l}{ Relative activity (\%) of strain } \\
\cline { 2 - 3 } & C3II & MP50 \\
\hline Naproxen nitrile & 100 & 100 \\
Benzylcyanide & 650 & 1400 \\
$\alpha$-Methylbenzylcyanide & 30 & 400 \\
$\alpha$-Ethylbenzylcyanide & 10 & 40 \\
$\alpha$-Methoxybenzylcyanide & $<1$ & 90 \\
Benzonitrile & 500 & nd \\
Naphthylcarbonitrile & nd & 2700 \\
Ibuprofen nitrile & $<1$ & $<1$ \\
Naproxen amide & 100 & 100 \\
Benzylamide & 400 & 20 \\
$\alpha$-Methylbenzylamide & 40 & 80 \\
Naphthylcarbamid & nd & 130 \\
\hline
\end{tabular}

nd, not determined; C3II Rhodococcus sp. C3II; MP50 Rhodococcus sp. MP50.

The strains were grown with succinate $(10 \mathrm{mM})$ and naproxen nitrile $(0.5 \mathrm{mM})$, harvested by centrifugation and resuspended in $\mathrm{Na} / \mathrm{K}$-phosphate buffer $(50 \mathrm{mM}, \mathrm{pH} 7.4)$ to an optical density $A_{546 \mathrm{~nm}}$ of 13 . The respective substrates were added $(0.5 \mathrm{mM}$ each) and the formation of the corresponding acids determined by HPLC analysis. For the nitriles the relative activities were compared with the value found with NapN taken as $100 \%$. The relative activities for the amides were related to the value determined with NapA taken as $100 \%$. The specific activities were: for strain C3II with NapN 0.011

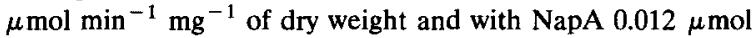
$\min ^{-1}$ per $\mathrm{mg}$ of dry weight; for strain MP50 with NapN $0.003 \mu \mathrm{mol} \mathrm{min}{ }^{-1}$ per mg of dry weight and with NapA 0.5 $\mu \mathrm{mol} \mathrm{min}^{-1} \mathrm{mg}^{-1}$ of dry weight.

\subsection{Substrate specificity of the naproxen nitrile and naproxen amide converting enzyme system}

Rhodococcus sp. C3II and MP50 were grown with succinate $(10 \mathrm{mM})$ and $\mathrm{NapN}(0.5 \mathrm{mM})$ and resting cells incubated with different nitriles and amides. Obviously both strains converted various subtituted nitriles and amides (Table 1).

\section{Discussion}

The microbial metabolism of nitriles proceeds via two different pathways. Nitrilases participate in the direct conversion of nitriles to their carboxylic acids and ammonia. The alternative pathway involves nitrile hydratases which mediate the conversion of nitriles to the corresponding amides. In a subsequent step amidases convert the amides to the corresponding carboxylic acids and ammonia (Harper, 1977a,b; Nagasawa et al., 1987, 1988a,b, 1990; Watanabe et al., 1987). The enzymatic hydrolysis of nitriles represents a very convenient synthetic method for amides and/or carboxylic acids due to the mild reaction conditions. Furthermore, these enzymatic reactions also allow the enantioselective synthesis of optical active amides and carboxylic acids from racemic precursors (Mayaux et al., 1990, 1991; Yamamoto et al., 1990; Kakeya et al., 1991; Bianchi et al., 1991; Bhalla et al., 1992; Cohen et al., 1992; Layh et al., 1992).

Rhodococcus sp. C3II and MP50 probably possess a nitrile hydratase and an amidase which hydrolyse naproxen nitrile or naproxen amide, respectively. Several other nitriles and amides were also converted. It was shown for both strains that the nitrile hydratase and the amidase are capable of hydrolysing their substrates with moderate to high enantiomeric excesses. Obviously the nitrile hydratase and amidase of Rhodococcus sp. C3II produced predominantly the $S$-enantiomers of naproxen amide or naproxen. It should be possible to use the purified nitrile hydratase from this strain to produce various $S$-amides from the corresponding racemic nitriles. In contrast, the nitrile hydratase from Rhodococcus sp. MP50 hydrolysed racemic NapN predominantly to $R$ NapA. Although both nitrile hydratases showed some enantioselectivity the high optical purity of $S$-naproxen formed was mainly due to the amidase reaction. For both isolates the amidase reaction occurred with high specificity allowing the recovery of both amide and acid with high optical activities.

Highly enantioselective amidases have also been observed by other investigators with various $\alpha$-substituted amides (Kieny L'Homme et al., 1981; Asano et al., 1989; Mayaux et al., 1990, 1991; Kakeya et al., 1991; Cohen et al., 1992). In general, these activities were found after screening of strains from culture collections or in bacteria which were initially enriched with different often aliphatic nitriles or amides. Later on these microorganisms were analyzed for the enantiose- 
lective hydrolysis of the substrate of interest. In the present study a different strategy was chosen and enrichments were carried out with the substrates to be biotransformed by the bacteria. Thus it was shown that bacteria could be obtained with the ability to hydrolyse enantioselectively naproxen nitrile to the industrially important compound $S$-naproxen.

Naproxen nitrile is only slightly soluble in water (about $0.04 \mathrm{mM}$ ). Therefore, bioavailability of NapN in water would be growth limiting. Similar problems are encountered in the bacterial degradation of polyaromatic hydrocarbons. Therefore we used a two-liquid-phase system for the enrichments. The observation that in two independent enrichments using NapN as sole nitrogen source bacteria were isolated only when pristane was present indicated a positive effect of this enrichment procedure.

\section{References}

Arsenijevic, L., Arsenijevic, V., Horea, A. and Jacques, J. (1973) 2-Acetyl-6-methoxynaphthalene. Organic Syntheses $53,5-8$.

Asano, Y., Mori, T., Hanamoto, S., Kato, Y. and Nakazawa, A. (1989) A new D-stereospecific amino acid amidase from Ochrobacterium anthropi. Biochem. Biophys. Res. Commun. 162, 470-474.

Battistel, E., Bianchi, D., Cesti, P. and Pina, C. (1991) Enzymatic resolution of $(S)-(+)$-Naproxen in a continuous reactor. Biotechnol. Bioeng. 38, 659-664.

Bhalla, T.C.., Miura, A., Wakamoto, A., Ohba, Y. and Furuhashi, K. (1992) Asymmetric hydrolysis of $\alpha$-aminonitriles to optically active amino acids by a nitrilase of Rhodococcus rhodochrous PA-34. Appl. Microbiol. Biotechnol. 37, 184-190.

Bianchi, D., Bosetti, A., Cesti, P., Franzosi, G. and Spezia, S. (1991) Stereoselective microbial hydrolysis of 2-aryloxypropionitriles. Biotechnol. Lett. 13, 241-244.

Brown, J.D. (1992) Asymmetric synthesis of naproxen via a pinacol-type reaction. Tetrahedron: Asymmetry 3, 15511552.

Caldwell, J., Hutt, A.J. and Fornel-Gigleux, S. (1988) The metabolic chiral inversion and dispositional enantioselectivity of the 2-arylpropionic acids and their biological consequences. Biochem. Pharmacol. 37, 105-114.

Castaldi, (i., Cavicchioli, S., Giordano, C. and Uggeri, F. (1987) Tartaric acid, an efficient chiral auxiliary: New asymmetric synthesis of 2-alkyl-2-arylacetic acids. J. Org. Chem. 52, 3018-3027.
Cohen, M.A., Parratt, J.S. and Turner, N.J. (1992) Enantioselective hydrolysis of nitriles and amides using an immobilised whole cell system. Tetrahedron: Asymmetry 3, 1543-1546.

Dorn, E., Hellwig,M., Reineke, W. and Knackmuss, H.-J. (1974) Isolation and characterization of a 3-chlorobenzoate degrading pseudomonad. Arch. Microbiol. 99, 61-70.

Franck, A. and Rüchardt, C. (1984) Optically active Naproxen by kinetic resolution. Chem. Lett., 1431-1434.

Giordano, C., Castaldi, G. and Uggeri, F. (1984) Synthese von entzündungshemmenden $\alpha$-Arylalkansäuren durch 1,2Arylverschiebung. Angew. Chem. 96, 413-419.

Gu, Q-M., Chen, C.-S. and Sih, C.J. (1986) A facile enzymatic resolution process for the preparation of $(+)-S-(6-$ methoxy-2-naphthyl)propionic acid (Naproxen). Tetrahedron Lett. 27, 1763-1766.

Hall, J.H. and Gisler, M. (1976) A simple method for converting nitriles to amides. Hydrolysis with potassium hydroxid in tert-butyl alcohol. J. Org. Chem. 41, 3769-3770.

Harper, D.B. (1977a) Microbial metabolism of aromatic nitriles. Enzymology of C-N-cleavage by Nocardia sp. (Rhodochrous group) NCIB 11216. Biochem. J. 165, 309318.

Harper, D.B. (1977b) Fungal degradation of aromatic nitriles. Enzymology of C-N-cleavage by Fusarium solani. Biochem. J. 167, 685-692.

Harrison, I.T., Lewis, B., Nelson, P, Rooks, W.H., Roszkowski, A.P., Tomolonis, A.J. and Fried, J.H. (1970) Non-steroidal anti-inflammatory agents. I. 6-Substituted-2-naphthylacetic acids. J. Med. Chem. 13, 203-205.

Hiyama, T., Inoue, M. and Saito, K. (1986) A facile route to $( \pm)$-2-arylpropanoic acids. Synthesis 645-647.

Kakeya, H., Sakai, N., Sugai, T. and Ohta, H. (1991) Microbial hydrolysis as a potent method for the preparation of optically active nitriles, amides and carboxylic acids. Tetrahedron Lett. 32, 1343-1346.

Kieny-L'-Homme, M.-P., Arnaud, A. and Galzy, P. (1981) Etude d'une $\mathrm{L}-\alpha$-aminoamidase particulaire de Brevibacterium sp. en vue de l'obtention d'acides $\alpha$-aminés optiquement actifs. J. Gen. Appl. Microbiol. 27, 307-325.

Layh, N., Stolz, A., Förster, S., Effenberger, F. and Knackmuss, H.-J. (1992) Enantioselective hydrolysis of $O$ acetylmandelonitrile to $O$-acetylmandelic acid by bacterial nitrilases. Arch. Microbiol. 158, 405-411.

Mayaux, J.-F., Cerbelaud, E., Soubrier, F., Faucher, D. and Petre, D. (1990) Purification, cloning and primary structure of an enantiomer-selective amidase from Brevibacterium sp. strain R312: Structural evidence for genetic coupling with nitrile hydratase. J. Bacteriol. 172, 67646773.

Mayaux, J.-F., Cerbelaud, E., Soubrier, F., Yeh, P., Blanche, F. and Petre, D. (1991) Purification, cloning and primary structure of a new enantiomer-selective amidase from a Rhodococcus strain: Structural evidence for a conserved genetic coupling with nitrile hydratase. J. Bacteriol. 173, 6694-6704.

Nagasawa, T., Nanba, H., Ryuno, K. and Talkeuchi, K. (1987) 
Nitrile hydratase of $P$ s. chlororaphis B23. Eur. J. Biochem. 162, 691-698.

Nagasawa, T., Ryuno, K. and Yamada, H. (1988a) Occurrence of a cobalt-induced and cobalt-containing nitrile hydratase in Rhodococcus rhodochrous J1. Biochem. Biophys. Res. Commun. 155, 1008-1016.

Nagasawa, T., Kobayashi, M. and Yamada, H. (1988b) Optimum culture conditions for the production of benzonitrilase by Rhodococcus rhodochrous J1. Arch. Microbiol. 150, 89-94.

Nagasawa, T., Mauger, J. and Yamada, H. (1990) A novel nitrilase, arylacetonitrilase, of Alcaligenes faecalis JM3. Eur. J. Biochem. 194, 765-772.

Parrinello, G. and Stille, J.K. (1987) Asymmetric hydroformylation catalyzed by homogeneous and polymer-supported platinum complexes containing chiral phosphine ligands. J. Am. Chem. Soc. 109, 7122-7127.

Roszkowski, A.P., Rooks, W.H. II, Tomolonis, A.J. and Miller, L.M. (1971) Anti-inflammatory and analgetic properties of D-2-(6'-methoxy-2'-naphthyl)-propionic acid (Naproxen). J. Pharmacol. Exp. Ther. 179, 114-123.

Shen, T.Y. (1972) Neuere nichtsteroidartige entzündungshemmende Wirkstoffe (Antiphlogistica). Angew. Chem. 84, 512-526.
Sonawane, H.R., Bellur, N.S., Ahuja, J.R. and Kulkarni, D.G. (1992) Recent developments in the synthesis of optically active $\alpha$-arylpropanoic acids: An important class of nonsteroidal anti-inflammatory agents. Tetrahedron: Asymmetry 3, 163-192.

Stanier, R.Y., Adelberg, E.A. and Ingraham, J.L. (1976) The microbial world, 4th edn., Prentice-Hall, Inc., Englewood Cliffs, NJ, USA.

Tsuchihashi, G., Mitamura, S., Kitajima, K. and Kobayashi, K. (1982) Synthesis of optically active 2-arylalkanoic acids by the use of 1,2-rearrangement of the aryl group. Tetrahedron Lett. 23, 5427-5430.

Watanabe, I., Satoh, Y. and Enomoto, K. (1987) Screening, isolation and taxonomical properties of microorganisms having acrylonitrile-hydrating activity. Agric. Biol. Chem. 51, 3193-3199.

Wolber, E.K.A. and Rüchardt, C. (1991) Neue Synthesen für Ibuprofen und Naproxen. Chem. Ber. 124, 1667-1672.

Yamamoto, K., Ueno, Y., Otsubo, K., Kawakami, K. and Komatsu, K.I. 1990. Production of $S$ - $(+)$-Ibuprofen from a nitrile compound by Acinetobacter sp. strain AK226. Appl. Environ. Microbiol. 56, 3125-3129. 